\title{
剛性履帯と超軟弱地盤との相互作用 \\ INTERACTION PROBLEM BETWEEN RIGID TRACK AND SUPER-WEAK MARINE SEDIMENT
}

\author{
室 達 朗*・河原荘一郎** \\ By Tatsuro MURO and Soichiro KAWAHARA
}

\begin{abstract}
This paper aims to analyse a trafficability of tracked vehicle of construction machinery operating on a super weak sediment of sea bed. Vane shear test result showed that the shear strength $c_{u}$ of kaolinite clay which is consolidated by its own weight in sea water increases lineary with depth. As the results of traction test for rigid track model with 4 grousers, the tractive resistance is in direct proportion to the height of grouser, and the average contact pressure of a track model is in proportion to a product of 0.216 power of grouser height and 0.598 power of initial sinkage. When an elasto-plastic FEM analysis concerning an increment of shear strength of soil to depth and its large deformation problem was used, the calculated values showed a qualitative agreement to the experimental data. And it was clarified that 1.5 times shear strength $c_{u}$ determined by vane test is of practical use for this FEM analysis.
\end{abstract}

Keywords: vehicle, rigid truck, weak ground, FEM analysis

\section{1. まえがき}

近年, 港湾整備, 海上空港や沈埋管トンネルの建設な ビ海底での施工が増加しつつある. わが国の大都市沿岸 部において工事対象となる河口，内湾では地盤支持力が あまり期待できない超軟弱地盤が広範囲に存在する.

ここでは，このような超軟弱地盤上を走行する履帯式 建設機械の走行性を把握することを目的とし, 履帯式水 中ブルドーザによる押土などの作業に必要な毫引力がど のような機構で発生するかについて着目し，超軟弱地盤 とその接触面である剛性履帯との相互作用について基礎 的な実験を行い, さらに有限要素法による解析を行った.

一般に, 牽引力は履帯の突起 (グラウザ) の間に挾ま れた土と地盤との間のせん断抵抗力（推進力）によって 発揮される. しかし, 推進力がすべて牽引力になるので はなく, 一部は地盤の沈下による圧縮やせん断変形に要 する走行抵抗のために消費される ${ }^{1)}$. 特に超軟弱地盤で は沈下量が大きいため推進力に対する走行抵抗の割合が かなり大きくなる.なお，ここでいう超軟弱地盤とは「自 然含水比が液性限界以上の地盤である」と定義する.

* 正会員 工博 愛媛大学教授 工学部海洋工学科 ( ₹790 松山市文京町 3)

** 正会員 工修 愛媛大学助手 工学部海洋工学科 (同上)
超軟弱地盤のモデルとして, 粉末のカオリン粘土を海 水と重量比 $2: 3$ で混合したのち 10 日間自重圧密した試 料土を用いた. 超軟弱地盤では自重により正規圧密して いるので, 非排水強度は深さ方向に直線的に増加する. そこで深さを変えてベーンせん断試験を行い, 非排水強 度と深さの関係を直線で表わした.

履帯は多くの履板がピンで連結されてできており，地 盤への変形の仕方の違いから,たわみ性履帯と剛性履帯 とに分けられる2). 剛性履帯の方がたわみ性履帯と比較 して接地圧分布が均一になるので沈下量が小さく，した がって剛性履帯の方が超軟弱地盤では走行抵抗を小さく し，有効毫引力を発揮するのに効果的である. そこで長 さ $40 \mathrm{~cm}$, 幅 $9 \mathrm{~cm}$, グラウザ枚数 4 枚の剛性履帯モデ ルについて試料土上で平面ひずみ状態において牽引試験 を行った，履帯の旁引特性に及ぼす要因として接地圧お よびグラウザ高さを取り上げ，それらの毫引抵抗および 沈下量に及ぼす影響を明らかにした。

さらに履帯モデルの毫引試験結果について試料土の深 さ方向の強度増加性を考慮した大変形弾塑性有限要素解 析を行った．この解析ではモールクーロンの降伏条件を 用い，関連流れ則を仮定するとともに増分法を用いた。 この解析結果と実験結果とを比較することによって, 解 析法の適用性を確かめた。 


\section{2. 履帯モデルの毫引試験}

（1）試 料 土

粉末のカオリン粘土を海水と $2: 3$ の重量比で混合し たのち, 後述する試料箱に入れ, 10 日間自重圧密（圧 密度 $95 \%$ ）したものを超軟弱試料土とした. Table 1 にその土質性状を示す．試料土の非排水せん断強度 $c_{u}$ を調べるため, 羽根の直径 $5.0 \mathrm{~cm}$, 高さ $9.3 \mathrm{~cm} の 4$ 枚 羽根を直角に取り付けたベーンを用いて，羽根の中央で の貫入深さを $5.0,7.5,10.0 \mathrm{~cm}$ と変えてせん断試験 を行った．せん断強度は深さ方向に直線的に増加してお り， $c_{u}$ が試料土表面で 0 になることを考慮に入れると， $c_{u}(\mathrm{~Pa})$ とせん断深さ $z(\mathrm{~cm})$ の関係は次式で表わさ れる.

$$
c_{u}=11.1 z
$$

\section{（2）履帯モデルおよび牽引装置}

この実験に使用した履帯モデルは, Fig. 1 に示す長さ $40 \mathrm{~cm}$ ，幅 $9 \mathrm{~cm}$ のアクリル製の平板に高さ $2 ， 3 ， 5,7$ $\mathrm{cm}$ のグラウザを取り付けたものおよびグラウザを取り 付けないものの 5 通りである.

この履帯モデルを旁引する装置を Fig. 2 に示す。この 装置はロッドの先端に直径 $30 \mathrm{~cm}$ のアクリル製の円盤 を取り付け，4 個の定滑車と 1 個の動滑車を介してその 円盤の 2 点に両端を固定したワイヤと，一端をその動滑 車に，もう一端を定滑車を介して履帯モデルに取り付け たワイヤを用い，円盤を回転させてワイヤを巻き取るこ とによって履帯モデルを水平に毫引し，そのときの牽引 抵抗をトルクセルによって検出し, 自記記録させるよう になっている. また，衰引試験中の履帯モデルの沈下量 は, 履帯モデルの前端と後端に取り付けたマークの挙動 をスライド撮影し読み取った。

試料箱は前面が透明のアクリル板でできており，100 $\times 40 \times 10 \mathrm{~cm}$ のものを使用した．また前面以外の面はべ

Table 1 Soil properties of kaolinite.

\begin{tabular}{|c|c|c|}
\hline \multicolumn{2}{|c|}{ Spec if ic gravity } & 2. 59 \\
\hline \multicolumn{2}{|c|}{ Plastic limit } & 31.2 \\
\hline \multicolumn{2}{|c|}{ Liquid limit } & 48.5 \\
\hline \multicolumn{2}{|c|}{ Plasticity index } & 17. 3 \\
\hline \multicolumn{2}{|c|}{ Liquidity index } & 455 \\
\hline \multirow{3}{*}{$\begin{array}{l}\text { Grain size } \\
\text { distribution }\end{array}$} & Coefficent of uniformity $\mathrm{Uc}$ & 1.73 \\
\hline & Coefficent of curvature $\mathrm{Cc}$ & 0.94 \\
\hline & Average grain size Dso $(\mu \mathrm{m})$ & 6.8 \\
\hline \multicolumn{2}{|c|}{ Unit weight } & 13.8 \\
\hline \multicolumn{2}{|l|}{ Void ratio } & 2.85 \\
\hline \multicolumn{2}{|c|}{ Water content } & 110 \\
\hline \multicolumn{2}{|c|}{ Degree of consolidation } & 95 \\
\hline \multicolumn{2}{|c|}{ Coefficent of consolidation $\mathrm{Cv}\left(\mathrm{cm}^{2} / \mathrm{s}\right)$} & $5.75 \times 10^{-4}$ \\
\hline
\end{tabular}

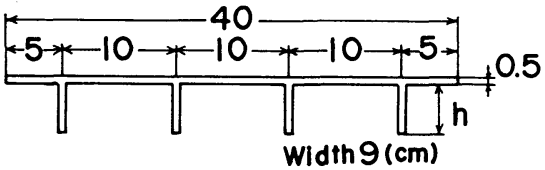

Fig. 1 Shape and dimension of track model.

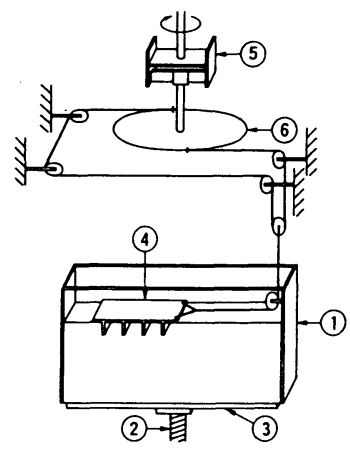
(1) Sample box
(2) Jack
(3) Table
(4) Track plate
(5) Torque cell
(6) Disk

Fig. 2 Test apparatus for traction of track model.

ニヤ板にビニローゼを塗布して，試料土との付着を取る ように心掛けた。なお，10日間圧密後に試料土の高さ が約 $30 \mathrm{~cm}$ になるように調整した。

\section{（3）沈下量に関する実験結果}

この実験では, 前述した 5 つのタイプの履帯モデルを 使用し，それぞれ平均接地圧が $0.29 ， 0.44 ， 0.59,0.74$, $0.88 ， 1.03 \mathrm{kPa}$ の 6 通りとなるように載荷した。牽引 速度はすべて $0.5 \mathrm{~cm} / \mathrm{s}$ で行った.

Fig. 3 にグラウザ高さ $h=3 \mathrm{~cm}$ の場合の牽引抵抗 $F$ および沈下量 $S$ と衰引距離 $X$ の関係を示す.ここで沈 下量 $S$ とは前後端の平均すなわち履帯モデル中央の値 であり，沈下量の基準を履帯モデルの腹下面にとり，そ れと試料土表面の距離で表わした。一般に沈下量とは鈆 直荷重による初期沈下量と履帯モデルの旁引に伴って発 生する傾斜荷重による沈下量(以後すべり沈下量という)

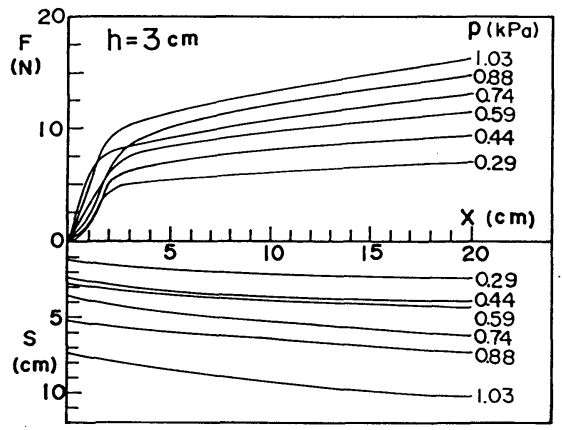

Fig. 3 Relations between tractive resistance $F$, sinkage $S$ and distance of traction $X$. 


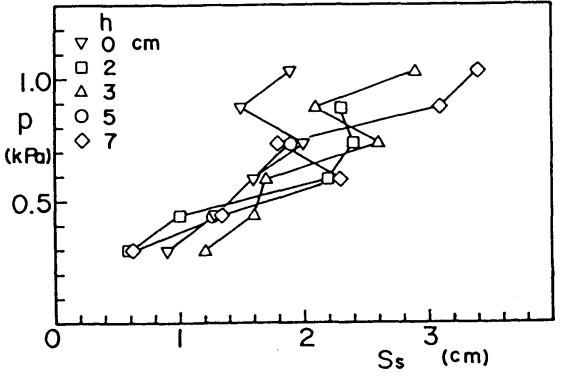

Fig. 4 Relations between average contact pressure $p$ and slip sinkage $S_{s}$ at $20 \mathrm{~cm}$ distance of traction.

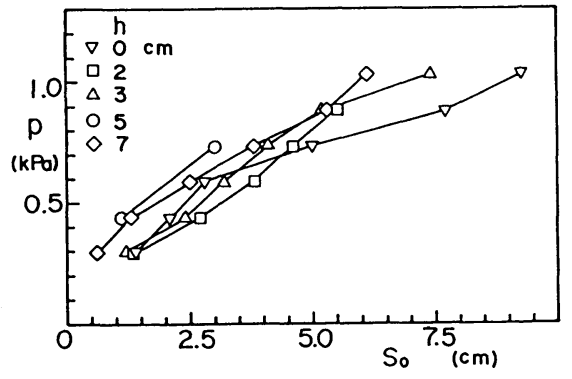

Fig. 5 Relations between average contact pressure $p$ and initial sinkage $S_{0}$.

Table 2 Values of $k$ and $n$ in Eq. ( 2 ).

\begin{tabular}{|c|c|c|c|}
\hline$h(c m)$ & $k$ & $n$ & $r$ \\
\hline 0 & 0.271 & 0.608 & 0.98 \\
\hline 2 & 0.216 & 0.807 & 0.99 \\
\hline 3 & 0.264 & 0.718 & 0.98 \\
\hline 5 & 0.420 & 0.509 & 1.00 \\
\hline 7 & 0.380 & 0.519 & 0.98 \\
\hline
\end{tabular}

$r$ : Correlation coef ficient

の和で与えられる.

すべり沈下量は旁引距離が増加するに従って増加す る. $20 \mathrm{~cm}$ 率引後のその值の平均は初期沈下量の 61.1 $\pm 24.0 \%$ であり, すべり沈下量と初期沈下量との間に は明暸な関係がみられない.

次に, $20 \mathrm{~cm}$ 率引後のすべり沈下量 $S_{s}$ と平均接地圧 $p$ の関係を Fig. 4 に示す.一般には平均接地圧が高くな るに従ってすべり沈下量も大きくなる傾向がみられる が, ある接地圧において一時的にすべり沈下量が減少す ることもある. また，すべり沈下量とグラウザ高さの間 には一定の関係がみられない.

初期沈下量 $S_{0}$ と平均接地圧 $p$ の関係を Fig. 5 に示 す. 初期沈下量はグラウザ高さの低いものほどわずかに 大きい. ところで $S_{0}(\mathrm{~cm})$ と $p(\mathrm{kPa})$ の間には次式
の関係 ${ }^{3), 4)}$ が一般に成立する.

$$
p=k S_{0}^{n}
$$

三次元の場合 $k=k_{c} / b+k_{\phi}$ が成立する.

\section{$b$ : 載荷幅}

$n$ (N.D.), $k_{c}\left(F / L^{n+1}\right), k_{\phi}\left(F / L^{n+2}\right)$ はともに平 板の寸法の影響を受けず，地盤の性質のみによって決ま る固有の值である. 杉山 ${ }^{5}$ は平板についての実験より一 般的な粘土では, $n=0.79, k_{c}=206, k_{\phi}=12(\mathrm{SI}$ 系で の換算値）であることを求めている.

この式はもともとグラウザのない平板に対して適用さ れたものであるが，二次元平面ひずみ条件で行った各グ ラウザ高さ別の $k, n$ の值を Table 2 に示す. グラウザ のない履帯モデル（すなわち平板である）を除いて考え ると， $k$ はグラウザ高さが高いほど大きくなる傾向があ る. 逆に $n$ はグラウザ高さが低いほよ゙大きくなる傾向 があり，一定とはならない。

このように係数 $k, n$ ともグラウザ高さ $h(\mathrm{~cm})$ の影 響を受けるので，この影響を含めて $h, S_{0}$ について重回 䚻分析を行うと次式が得られた。

$$
p=0.240 h^{0.216} S_{0}^{0.598}
$$

(重相関係数 0.96 )

この式では, $S_{0}$ の指数の值はグラウザのない場合とほ ぼ等しく,グラウザの有無の影響を受けない。

\section{（4）抵抗に関する実験結果}

前述の Fig. 3 をみると衰引距離約 $3 \mathrm{~cm}$ まで牽引抵抗 は急激に増加し，その後はなだらかに増加する傾向がみ られる. また, 平均接地圧が高いほど毫引抵抗は大きい. これらのことは他のグラウザ高さの履帯モデルでもみら れた.

次に, Fig. 6 に種々の平均接地圧 $p$ に対する $20 \mathrm{~cm}$ 毫 引後の牽引抵抗 $F_{20}$ とグラウザ高さ $h$ との関係を示す. 牽引抵抗とグラウザ高さとの間にはほぼ比例関係がみら れる.これは视下量がグラウザ高さの影響をほとんど受 けないため,グラウザ先端でのせん断深さがグラウザ高

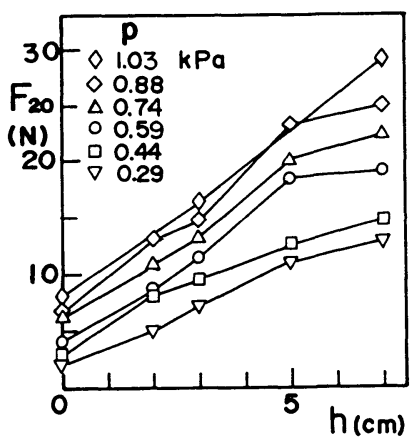

Fig. 6 Relations between tractive resistance $F_{20}$ at $20 \mathrm{~cm}$ distance of traction and height of grouser $h$. 
Table 3 Values of $a_{0}, a_{1}$ and $a_{2}$ in Eq. (4).

\begin{tabular}{|c|c|c|c|c|}
\hline $\mathrm{h}(\mathrm{cm})$ & $\mathrm{a}_{0}$ & $\mathrm{a}_{1}$ & $\mathrm{a}_{2}$ & $\mathrm{R}$ \\
\hline 0 & 3.90 & 0.237 & 1.170 & 0.99 \\
\hline 2 & 7.66 & 0.187 & 0.718 & 0.99 \\
\hline 3 & 7.41 & 0.245 & 0.622 & 1.00 \\
\hline 5 & 12.71 & 0.200 & 0.618 & 0.97 \\
\hline 7 & 16.06 & 0.166 & 0.635 & 0.99 \\
\hline
\end{tabular}

$R$ : Multiple correlation coefficient

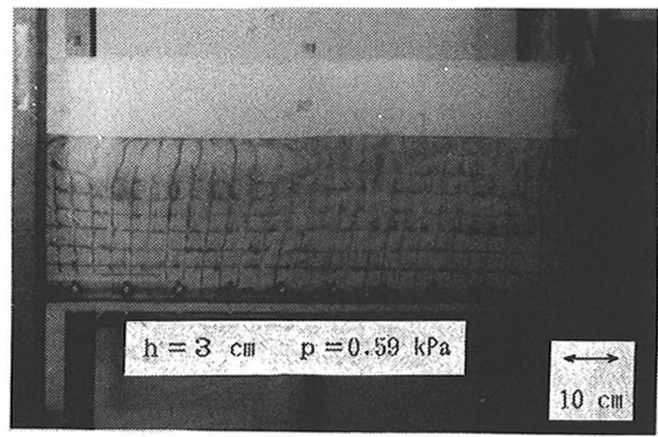

(a) at initial sinkage

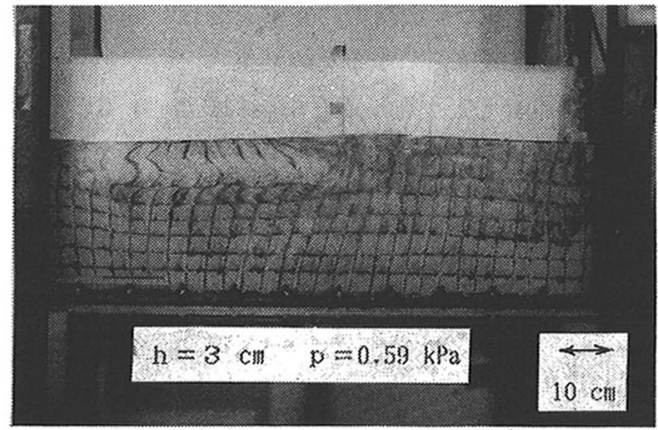

(b) at $5 \mathrm{~cm}$ distance of traction

Photo1 Failure pattern under track model.

さに比例するためであると考える.

さて, 説明変数を $X(\mathrm{~cm})$ および $p(\mathrm{kPa})$, 被説明 変数を $F(\mathrm{~N})$ として重回帰分析を行った結果, 次式の 関係が得られた。

$$
F=a_{0} X^{a 1} p^{a 2} \text {. }
$$

係数 $a_{0}, a_{1}, a_{2}$ の值は Table 3 に示すとおりである. $a_{0}$ はグラウザ高さが高いほど大きいが，グラウザがない場 合を除いて $a_{1}, a_{2}$ はグラウザ高さの影響をあまり受け ず,それぞれ平均 $0.200 \pm 0.029,0.648 \pm 0.041$ であった.

ところで星引抵抗と沈下量の関係についてみると, 沈 下量が大きいほど率引抵抗も大きくなっている．これは 沈下量が大きいほどグラウザ先端でのせん断深さが深い
ためにせん断強度が大きくなるからである.

\section{（5）試料土の挙動}

Photo 1(a), (b) はグラウザ高さ $h=3 \mathrm{~cm}$, 平均接地 圧 $p=0.59 \mathrm{kPa}$ の場合のそれぞれ鉛直荷重による載荷 直後, $5 \mathrm{~cm}$ 率引後の試料土の挙動である. 同図 (a) で は履帯モデル両端部の縦線は外側に湾曲しているのに対 し，履帯モデル中央部ではグラウザ間に㣣まれた試料土 が, グラウザによって変位拘束されているため, そのよ うな変形はみられない，一方, 同図 (b) ではグラウザ 下端を結ぶ線上で縦線が牽引方向にくの字に曲がった形 状をしており, またそれより梁い位置の縦線もグラウザ 先端から約 $6 \mathrm{~cm}$ に至るまで牽引方向に傾いている.

このように超軟弱地盤では滑り線ははっきりしたもの でなく，せん断領域がグラウザ先端位置より深いところ まで及んでいる. したがって従来のグラウザ先端を結ぶ 線上にすべり線を仮定した理論间.7)では率引抵抗は過小 に評価される. また, この理論では履帯モデルの沈下量 を考慮していないため次節で有限要素解析によって詳細 に検討する。

\section{3. 有限要素解析}

\section{（1）解析方法}

履帯モデルの旁引試験結果について有限要素法を用 い，関連流れ則を仮定するとともに增分法を用いること によって大変形弾塑性解析を行った．降伏条件および塑 性ポテンシャルは平面ひずみ状態における次式の粘土 （c 材）に対するモールクーロンの基準（すなわちこの 場合はトレスカの基準と等しい) を用いた.

$\bar{\sigma}=\sigma_{1}-\sigma_{3} \leqq q_{u}$

$\bar{\sigma}:$ 相当応力, $\sigma_{1}, \sigma_{3}:$ 最大, 最小主応力

$q_{u}:$ 一軸圧縮強度

弾性限度を越えたところの応力増分一ひずみ関係は，山 田の方法 ${ }^{81}$ により次式のように求められる.

$$
\begin{aligned}
& {\left[\begin{array}{l}
d \sigma_{x} \\
d \sigma_{y} \\
d \tau_{x y}
\end{array}\right]=\left[D_{e}\right]\left[\begin{array}{c}
d \varepsilon_{x} \\
d \varepsilon_{y} \\
d \gamma_{x y}
\end{array}\right]-\frac{4 G^{2}}{\bar{\sigma}^{2}\left(4 G^{2}+H^{\prime}\right)} } \\
& \cdot\left[\begin{array}{ccc}
\sigma^{2} & -\sigma^{2} & 2 \sigma \tau_{x y} \\
-\sigma^{2} & \sigma^{2} & -2 \sigma \tau_{x y} \\
2 \sigma \tau_{x y} & -2 \sigma \tau_{x y} & 4 \tau_{x y}^{2}
\end{array}\right]\left[\begin{array}{c}
d \varepsilon_{x} \\
d \varepsilon_{y} \\
d \gamma_{x y}
\end{array}\right]
\end{aligned}
$$

$$
\sigma=\sigma_{x}-\sigma_{y}
$$

$\left[D_{e}\right]$ : 平面ひずみ状態における弾性の応力ーひずみマ トリックス, $E$ : 弾性係数, $\nu:$ ポアソン比, $G$ : 剛 性率, $H^{\prime}:$ ひずみ硬化率

弾塑性の構成方程式は, 右辺第 1 項の弾性の構成方程式 を第 2 項によって補正する形となっているが，この補正 項は見掛けの応力増分として扱った．また，引張破壊し 


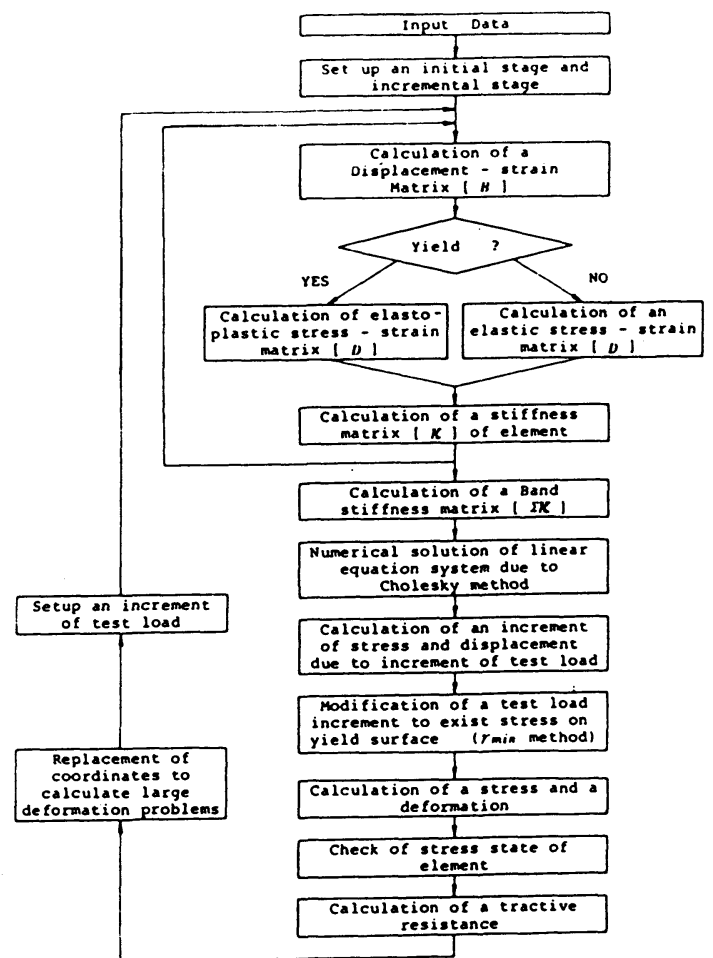

Fig. 7 Flow chart of FEM programming due to elasto-plastic theory.

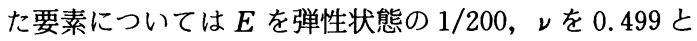
して処理した.

Fig. 7 にこの解析に用いたプログラムのフローチャー トを示す。このプログラムでは，ある試験的な荷重増分 あるいは強制変位増分に対して相当応力 $\bar{\sigma}$ を計算し, 弾性状態の要素について $\bar{\sigma}$ が $q_{u}$ を越えないよう, すな わち降伏曲面上に応力值が存在するように $r_{\min }$ 法を用 いて試験的な荷重増分あるいは強制変位増分を修正する ようになっている. また連立一次方程式の解法として， 剛性マトリックス $[\Sigma K]$ の対称性を利用したコレス キー法をバンド化して用いている.

\section{（2）解析条件}

解析対象の履帯モデルの形状および寸法は前述 Fig. 1 のとおりであるが, グラウザ高さ $h$ は $3,5,7 \mathrm{~cm}$ に限っ た. 解析に用いた試料土の物性值を Table 4 に示す. $c_{u}$ $\left(=q_{u} / 2\right)$ および $E\left(=E_{50}\right)$ はベーン試験より定めた が, 自重王密している超軟弱地盤の特長である深さ方向 に直線的に大きくなることを解析に取り入れた。 また, $c_{u}$ を 2 通り用いたが，小さい方が実際にベーン試験よ り定めたもの（以下(1)という）であり，大きい方はその 值を 1.5 倍したもの（以下(2)という）である. 一般に地 盤はせん断強度異方性があるが，ベーンでは主に鉛直方 向のせん断強度 $\tau_{v}$ を求めている，履帯モデルの旁引試
Table 4 Soil properties for FEM analysis.

\begin{tabular}{|lc|c|}
\hline Modulus of elasticity & $\mathrm{E}_{50}(\mathrm{~Pa})$ & $170 \mathrm{z}$ \\
\hline Undrained shear strength & $\mathrm{Cu}(\mathrm{Pa})$ & $11.1 \mathrm{z}$ \\
\cline { 3 - 4 } & & $16.6 \mathrm{z}$ \\
\hline Strain-hardening rate & $\mathrm{H}^{\prime}(\mathrm{Pa})$ & $0.001 \mathrm{E} 50$ \\
\hline Poisson's ratio & $\nu$ & 0.490 \\
\hline \multicolumn{4}{|l}{$\mathrm{z}:$ Depth } \\
\hline
\end{tabular}

験では試料土は主に水平方向にせん断されているので水 平方向のせん断強度 $\tau_{H}$ を求める必要がある．ここでは 塑性指数 $I_{P}$ と水平方向と鉛直方向とのせん断強度の比 $\tau_{H} / \tau_{V}$ の関係 ${ }^{9)}$ より $I_{P}=17.3 \%$ である本試料土では $\tau_{H} / \tau_{V} \fallingdotseq 1.5$ となるので, (2)では $c_{u}$ を 1.5 倍したものに ついて解析した.

また，弾性係数はベーン試験結果より以下のとおりに 定めた。

Cadling, Odenstad ${ }^{10)}$ は, ベーン試験結果から土の剛 性率 $G$ を求めることを目的として，二次元弾性論に基 ゔく考察を行い，剛性率 $G$ を次式のように求めた。

$G=\tau /(2 \theta)$

$\tau$ : せん断応力, $\theta$ : 回転角 $(\mathrm{rad})$

この解析では弾性係数として $E_{50}$ を定めるため， $G_{50}$ を 次式のように表わした"11).

$$
G_{50}=\frac{c_{u} / 2}{2 \theta_{a}}
$$

$\theta_{a}: \tau=c_{u} / 2$ における回転角

これより $G=E / 2(1+\nu)$ なる関係を用い, また深さ方 向に $G_{50}$ が直線的に増加しており，試料土表面で $G_{50}$ が 0 となるとみなすと $E_{50}(\mathrm{~Pa})$ と深さ $z(\mathrm{~cm})$ の間に Table 4 の関係が得られた。 なお，同表における $z$ は各 要素の重心位置の鉛直座標で評価した. ポアンン比 $\nu$ については,牽引中に試料土の体積変化がないものとし, 0.490 とし, 試料土の引張強度は $c_{u}$ と等しくした.

一方, 履帯モデルについてはせん断, 引張破壊しない と考え, 弾性係数 $E=4.90 \mathrm{MPa}$, またポアソン比 $\nu=$ 0.3 と便宜的に与えた.

解析領域については履帯モデルの旁引試験と同じ領域

Table 5 Number of triangular elements and nodal points.

\begin{tabular}{|c|c|c|}
\hline $\begin{array}{l}\text { Height of } \\
\text { grouser } \\
\text { h } \\
(\mathrm{cm})\end{array}$ & $\begin{array}{l}\text { Number of } \\
\text { element }\end{array}$ & $\begin{array}{l}\text { Number of } \\
\text { nodal po int }\end{array}$ \\
\hline 3 & 429 & 235 \\
\hline 5 & 451 & 246 \\
\hline 7 & 509 & 275 \\
\hline
\end{tabular}




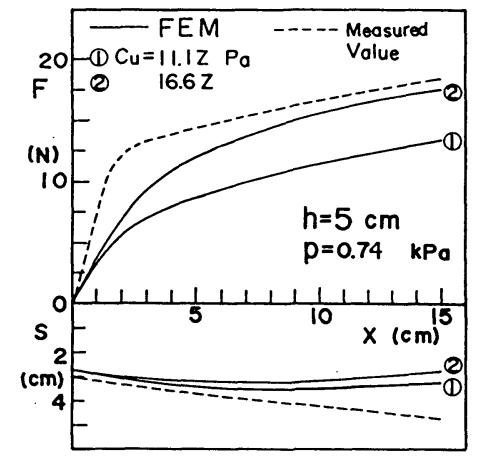

Fig. 8 Relations between tractive resistance $F$, sinkage $S$ and distance of traction $X$ (comparison between calculated values due to FEM and measured values).

(長さ $100 \mathrm{~cm} \times$ 高さ $30 \mathrm{~cm}$ ) である. 履帯モデルと試 料土が接する節点ではその間の付着力によりスリップが ないものとして扱った。また試料土と試料箱内面との境 界条件は, 鉛直面に対しては鉛直方向, 水平面に対して は水平方向の変位を許すものとした．要素形状は 3 角形 要素であり, 各グラウザ高さ $h$ ごとに要素数, 節点数 をTable 5 に示す.

\section{(3) 解析結果}

Fig. 8 に一例としてグラウザ高さ $h=5 \mathrm{~cm}, p=0.74$ $\mathrm{kPa}$ の場合の解析結果を示す. ベーンせん断試験より 求めた $c_{u}$ を用いた(1)の場合, FEM 計算值の牽引抵抗 $F$ は実験値のものより小さくなっている.これはFEM 計算値の沈下量 $S$ が実験值より小さいため, グラウザ 先端でのせん断深さが浅くなるのでせん断強度が小さい ことによる. 実際, $p=0.74 \mathrm{kPa}$ の接地圧になると履帯 モデルの上に試料土が覆いかぶさり, 接地圧が設定值よ り多少高くなるので FEM 計算值の沈下量 $S$ は実験値 より小さいと考える. また(1)の $c_{u}$ を 1.5 倍した(2)の場 合, やはり FEM 計算値の毫引抵抗 $F$ は実験値のもの より小さくなっている. (1)と比較した場合，Fの值は
約 1.5 倍となっているが $S$ の値はわずかに小さいだけ である.

次に, グラウザ高さ $h=5 \mathrm{~cm}, p=0.59 \mathrm{kPa}$ の場合の $5 \mathrm{~cm}$ 毫引後の試料土の変形および破壊状態を Fig. 9 に 示す. せん断破壊域はグラウザ先端より約 $8 \mathrm{~cm}$ まで及 んでいる. FEM 解析では 3 角形要素を使用しているた め要素内で一定の応力値しか取り得ないので, グラウザ 先端からの破壊域の梁さは実験値とほぼ一致していると いえる. 一方，グラウザ間に挾まれた試料土ではグラウ ザによって変位を拘束されているため，ほとんど変形し ておらず，弾性域となっている．また，進行方向の破壊 域は先頭のグラウザ先端より約 $30 \mathrm{~cm}$ 前方まで及んで いる.

\section{(4) 考 察}

牽引抵抗および沈下量の FEM 計算値が推定値とし て適切かどうかを実験值と比較することによって検討し た。

Fig. 10 は $10 \mathrm{~cm}$ 毫引後の旁引抵抗 $F_{10}$ と平均接地圧

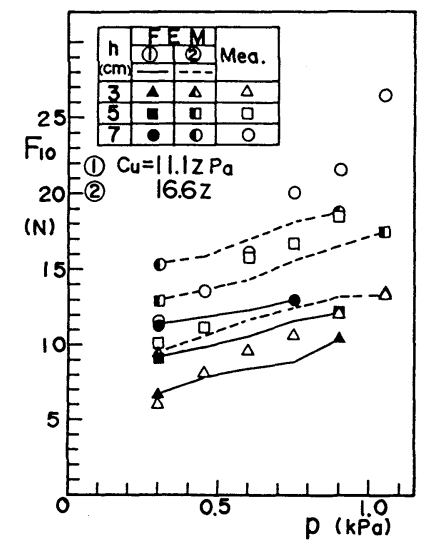

Fig. 10 Relations between tractive resistance $F_{10}$ at $10 \mathrm{~cm}$ distance of traction and average contact pressure $p$ (comparison between calculated values due to FEM and measured values).

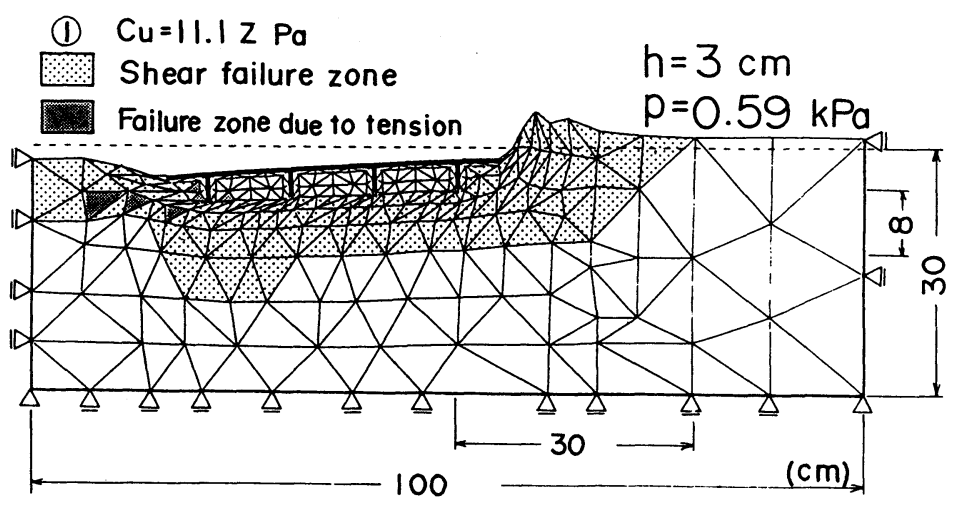

Fig. 9 Failure pattern of each element at $5 \mathrm{~cm}$ distance of traction. 


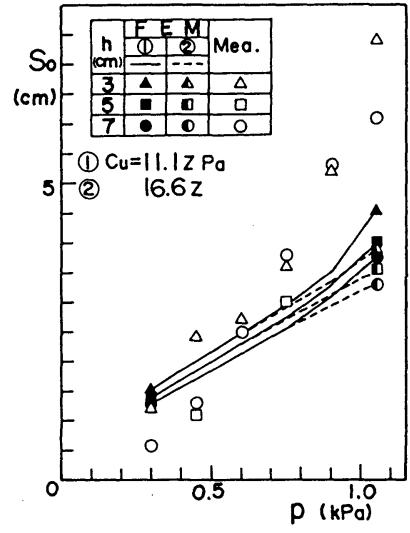

Fig. 11 Relations between initial sinkage $S_{0}$ and average contact pressure $p$ (comparison between calculated values dure to FEM and measured values).

$p$ の関係における FEM 計算値と実験値の比較を示した ものである. (1)，(2)の場合にかかわらず，FEM 計算值 の $F_{10}$ は接地圧が高くなるに従って，またグラウザ高さ が高くなるに従って大きくなっている．この点からみる と, FEM 解析結果は実験結果と同様の傾向を示してい る. しかし, (1)の FEM 計算値の $F_{10}$ は $p=0.44 \mathrm{kPa}$ 以下の接地圧では実験值とほとんど変わらないが, それ 以上の接地圧になると接地圧が高くなるに従って実験值 よりかなり小さくなっている.この主な原因は前述した ようにこの FEM 解析では毫引中に履帯モデル上に試 料土が覆いかぶさることを考慮できないためと考える. ところで, (2)の場合, (1)と比べて相対的に高い接地圧で 実験値とよく一致している. 超軟弱地盤では有効旁引力 が最大となる最適接地圧が $1.0 \mathrm{kPa}$ 程度である ${ }^{12), 13)}$ とを考えると，便宜的にはベーンせん断試験で得られた $c_{u}$ を約 1.5 倍したせん断強度を解析に用いればよい。

さらに，前述の Fig. 9 において(1)の場合のせん断破壊 域の広さは実験值と同じかもしくは大きいのにもかかわ らず,牽引抵抗は実験值より小さいことを考えると,ベー ンせん断試験で求めた $c_{u}$ より大きい值をこの解析には 使用すべきである.なお，ベーンによるせん断機構 ${ }^{14}$ が 試料土の異方性を十分に評価し得る ${ }^{9)}$ とはいえ, 履帯下 のせん断と塑性流動による破壊域の拡大を考えるとべー ンによる試験法が最も適切なものかどうかは疑問であ る. 今後, 比掘削抵抗 $\left.{ }^{15)}, 16\right)$ からせん断特性を求める方向 で検討する必要がある.

次に, Fig. 11 に初期沈下量 $S_{0}$ と平均接地圧 $p$ の関係 における FEM 計算値と実験値の比較を示す. (1), (2) の場合にかかわらず, FEM 計算値の $S_{0}$ は接地圧が高 くなるに従って，またグラウザ高さが低くなるに従って 大きくなっている．この点からみると牽引抵抗の場合と
同様に, FEM 解析結果は実験結果と同様の傾向を示し ている. (1), (2)とも $p=0.74 \mathrm{kPa}$ 以下の接地圧では FEM 計算値の $S_{0}$ は実験値とほとんど変わらないが, それ以上の接地圧になると実験値より小さくなってい る. また，(1)と(2)を比較すると, $p=0.74 \mathrm{kPa}$ 以上の接 地圧で(2)の方が(1)より幾分小さくなっているだけであ り，相違はほとんどみられない。

\section{4. 結 論}

超軟弱地盤ではせん断強度が深さ方向に直線的に増加 しており，そのことが剛性履帯の荤引力および沈下量の 牽引性能に対して深く影響を及ぼしている.

ここでは, 超軟弱地盤における剛性履帯モデルの毫引 試験およびその有限要素解析から履帯と超軟弱地盤の相 互作用に関して次のことが明らかとなった。

（1）剛性履帯モデルの旁引試験より，グラウザのあ る履帯モデルについて, 初期沈下量 $S_{0}(\mathrm{~cm})$ と平均接 地圧 $p(\mathrm{kPa})$ およびグラウザ高さ $h(\mathrm{~cm})$ の間には次 式の関係が成立する.

$p=0.240 h^{0.216} S_{0}^{0.598}$

この式の $S_{0}$ の指数はグラウザのない場合の 0.608 とほ ぼ等しく,グラウザの有無の影響を受けない.

（2） 牽引抵抗 $F(\mathrm{~N})$ と牽引距離 $X(\mathrm{~cm})$ および $p(\mathrm{kPa})$ の間には次式の関係が成立する.

$F=a_{0} X^{a_{1}} p^{a_{2}}$

$a_{0}$ はグラウザ高さが高いほど大きいが，グラウザがな い場合を除いて $a_{1}, a_{2}$ はグラウザ高さの影響をあまり 受けず，それぞれ平均 $0.200 \pm 0.029,0.648 \pm 0.041$ で あった．また，旁引抵抗はグラウザ高さに比例する.

（3）超軟弱地盤ではすべり線ははっきりしたもので なく, $p=0.59 \mathrm{kPa}$ の場合ではせん断領域がグラウザ先 端位置より約 $6 \mathrm{~cm}$ の深いところまで及んでいる.

(4) 大変形弾塑性有限要素解析結果の牽引抵抗およ び沈下量は定性的には実験結果之一致する.

（5） ベーンせん断試験より求めた非排水強度 $c_{u}$ を 有限要素解析に用いた場合, $p=0.59 \mathrm{kPa}$ 以上の高い接 地圧での実験値より過小になっており，したがって実用 的には $c_{u}$ の值を 1.5 倍したものを解析に用いればよ い.

今後は, 三角形等のグラウザをもつ履帯に関してグラ ウザ形状と毫引性能の関係について明らかにしていく予 定である. 最後に本研究を行うに際して, 愛媛大学元学 生 古田真二氏, 赤坂雄司氏, 水川泰一氏に多大なるご 協力を得たことを記して謝意を表する.

1）杉山 昇：建設機械と土の諸問題, pp. 90 133, 鹿島出 
版会, 1982.

2) Karafiath, L. L. and Nowatzki, E. A. : Soil Mechanics for Off-Road Vehicle Engineering, pp. 429 481, Trans. Techpublications, 1978.

3) Bekker, M. G. : Introduction to Terrain-Vehicle Systems, pp. 38 114, The University of Michigan Press. , 1969.

4) Youssef, A.F. and Ali, G.A. : Determination of soil parameters using plate test, J. Terramechanics, Vol.19, No. 2, pp. 129 147, 1982.

5）杉山 昇：装軌車両のけん引力に関する土質工学的考察 (第 1 報)，土と基礎，第 20 巻 11 号, pp. 49 56, 1972.

6) Masuda, S., Tanaka, T. and Oida, A. : Soil deformation under model shoe and its reaction evaluated from shear stress-strain characteristics, Proc., 3rd Int. Cof. ISTVS, Vol.2, pp. 25 49, 1969.

7）笼田 昭: 装軌トラクタのけん引性能解析, 農業機械学 会誌, 第 38 巻 1 号, pp. 25 40, 1976.

8）山田嘉昭：有限要素法の基礎之応用シリーズ 2. マトリッ クス法材科力学, pp. 37〜 53, 培風館, 1980 .

9) Richardson, A.M., Brand, E.W. and Memon, A. : In-situ determination of anisotropy of a soft clay, Proc. of the Conf. In-situ Measurement of Soil Properties, ASCE, Vol.1, pp. 336 349, 1975.
10) Cadling, L. and Odenstad, S. : The vane borer. an apparatus for determining the shear strength of clay directly in the ground, Proc., Royal Swedish Geotechnical Institute, No.2, 1950.

11) Muro, T. : Interaction between super-weak marine sediment and track plate of construction machinery, Memoirs of the Faculty of Engineering, Ehime University, Vol. X, No. 3, pp. 421 432, 1984.

12）室 達朗・榎 明挲：超軟弱地盤における履帯式車轌の 走行性能, 愛媛大学工学部紀要, Vol. X, No. 2, pp. 329 $\sim 338,1983$.

13）室 達朗・河原荘一郎・尾本 清：建設機械用履帯のグ ローサ間隔と毫引力の関係，第 38 回土木学会中国四国支 部研究発表会講演概要集, pp. 291 292, 1986.

14）柴田 徹：粘土のベーンせん断強度に関する研究, 土木 学会論文集, 第 138 号, pp. 39 48, 1967.

15) Hata, S. : A field test for the specific cutting resistance, Proc., 6th Int. Conf., ISTVS, Vol. 3, Vienna, Austria, pp. 983 992, 1978.

16）畠昭治郎・檜垣義雄・建山和由：水底粘土地盤の掘削に ついて, 土木学会第 35 回年次学術講演会講演概要集 3 , pp. 450 451, 1980.

(1986. 7.21 - 受付) 